\title{
Changes of temperature-related agroclimatic indices in Poland
}

\author{
D. Graczyk • Z. W. Kundzewicz
}

Received: 25 March 2014 / Accepted: 5 March 2015 / Published online: 17 March 2015

(C) The Author(s) 2015. This article is published with open access at Springerlink.com

\begin{abstract}
The agricultural sector in Poland is of considerable social and economic importance for the nation. Climate variability and change are of primary relevance to this largely climate-dependent sector. Changes in seven temperature-related agroclimatic indices (lengths of the growing season and of the frost-free season, days of occurrence of the last spring frost and of the first autumn frost; and annual sums of growing degree-days for three values of temperature threshold) in Poland in 1951-2010 are examined. As expected, they generally correspond to the overwhelming and ubiquitous warming. Many, but not all, detected trends are statistically significant. However, for some indices, strong natural variability overshadows eventual trends. Projections of temperature-related agroclimatic indices for the future, based on regional climate models, are also discussed.
\end{abstract}

\section{Introduction}

The agricultural sector in Poland is very important, socially and economically. The area of agricultural land in the country reaches approx. 187,000 $\mathrm{km}^{2}$ (as compared to the total area of the country of $312,000 \mathrm{~km}^{2}$ ). There are over 2.1 million people in Poland employed in agriculture, and this sector generates approx. $3 \%$ of the GDP and over $9 \%$ of the value of

D. Graczyk $(\bowtie) \cdot$ Z. W. Kundzewicz

Institute for Agricultural and Forest Environment, Polish Academy of Sciences, Poznań, Poland

e-mail: darekgraczyk@wp.pl

Z. W. Kundzewicz

e-mail: kundzewicz@yahoo.com

Z. W. Kundzewicz

Potsdam Institute for Climate Impact Research, Potsdam, Germany national export. Poland is predominantly a lowland country. Over three fourths of the country area is located at elevation below $200 \mathrm{~m}$ a.m.s.l.

The climate of Poland is moderate and ranges from maritime to continental. Over the country, humid Atlantic air from the west collides with dry continental air from the east. In addition to spring, summer, autumn, and winter, there are two transitional seasons - early spring (przedwiośnie) and early winter (przedzimie) with mean daily temperatures between 0 and $5{ }^{\circ} \mathrm{C}$. Inter-annual variability of seasonal temperature is strong, particularly for winters, that can be warm - more oceanic or cold - more continental.

Since agriculture largely depends on climate, the climate change (both observed and projected) is of considerable interest and importance to the sector. In general, agriculture in Europe is temperature-limited in the north and water-limited in the south. Poland is located in the transition zone between these two conditions.

Climate change and overwhelming warming influence temperature-related agroclimatic indices. Climatic conditions related to temperature impact upon the size of harvest and the time of sewing, planting, and harvesting. Hence, improving the insight into changes of important temperature-related indices is of considerable societal and economic importance. The present paper starts by discussion of data and methods used, specification of seven indices of relevance, and information on the test. Next, results of change detection in three sets of indices, i.e., (i) lengths of the growing season and of the frost-free season, (ii) dates of occurrence of the last spring frost and of the first autumn frost, and (iii) annual sums of growing degree-days for three temperature threshold values are presented. Further, model-based projections for the future are reviewed.

Many results shown in the present paper draw from the doctoral thesis of Graczyk (2013), prepared under the supervision of the second author of this paper. 


\section{Data and methods}

The violent history of Poland in the 20th century, embracing armed conflicts, major changes of national boundaries including discontinuity of independent statehood, considerably limited the number and length of existing time series of meteorological data. Furthermore, such data are not readily available in open access. Nevertheless, the authors could access and compile time series of daily temperature (mean, maximum, and minimum values) for 22 meteorological stations in Poland. These stations read Bielsko-Biała, Chojnice, Hel, Jelenia Góra, Kalisz, Kasprowy Wierch, Katowice, Legnica, Lesko, Łódź, Poznań-Ławica, Rzeszów, Słubice, Suwałki, Szczecin, Śnieżka, Świnoujście, Toruń, Warszawa-Okęcie, Włodawa, Wrocław, Zakopane (Table 1, Fig. 1). The basic criteria of selection of stations were the length of the available time series of records, covering at least the interval 1951-2010 and spatial distribution of stations covering, in a reasonably uniform way, the whole territory of Poland, and reflecting the variability of its climates. In addition, Graczyk (2013) also examined several foreign stations, some of which, such as

Table 1 Listing of meteorological stations used in this work, their geographic coordinates and altitude

\begin{tabular}{|c|c|c|c|c|c|}
\hline \multirow[t]{2}{*}{ No. } & \multirow[t]{2}{*}{ Station name } & \multicolumn{2}{|c|}{$\begin{array}{l}\text { Geographic } \\
\text { coordinates }\end{array}$} & \multirow[t]{2}{*}{$\begin{array}{l}\text { Altitude } \\
\text { (m a.s.1.) }\end{array}$} & \multirow{2}{*}{$\begin{array}{l}\text { Mean annua } \\
\text { temperature } \\
2001-2010 \\
\left({ }^{\circ} \mathrm{C}\right)\end{array}$} \\
\hline & & $\begin{array}{l}\text { Latitude } \\
\text { (deg.) }\end{array}$ & $\begin{array}{l}\text { Longitude } \\
\text { (deg.) }\end{array}$ & & \\
\hline 1 & Bielsko-Biała & 19.00 & 49.80 & 398 & 8.8 \\
\hline 2 & Chojnice & 17.55 & 53.70 & 172 & 7.9 \\
\hline 3 & Hel & 18.82 & 54.60 & 1 & 8.7 \\
\hline 4 & Jelenia Góra & 15.80 & 50.90 & 342 & 7.8 \\
\hline 5 & Kalisz & 18.08 & 51.73 & 140 & 9.1 \\
\hline 6 & Kasprowy Wierch & 19.98 & 49.23 & 1991 & 0.0 \\
\hline 7 & Katowice & 19.08 & 50.48 & 317 & 8.8 \\
\hline 8 & Legnica & 16.17 & 51.22 & 122 & 9.5 \\
\hline 9 & Lesko & 22.33 & 49.47 & 386 & 8.0 \\
\hline 10 & Łódź & 19.40 & 51.73 & 187 & 8.6 \\
\hline 11 & Poznań-Ławica & 16.83 & 52.42 & 86 & 9.2 \\
\hline 12 & Rzeszów & 22.05 & 50.10 & 200 & 8.7 \\
\hline 13 & Słubice & 14.60 & 52.35 & 21 & 9.4 \\
\hline 14 & Suwałki & 22.95 & 54.13 & 184 & 7.1 \\
\hline 15 & Szczecin & 14.62 & 53.40 & 1 & 9.4 \\
\hline 16 & Śnieżka & 15.73 & 50.73 & 1603 & 1.3 \\
\hline 17 & Świnoujście & 14.23 & 53.92 & 6 & 9.1 \\
\hline 18 & Toruń & 18.58 & 53.05 & 69 & 8.7 \\
\hline 19 & Warszawa-Okęcie & 20.98 & 52.15 & 106 & 8.8 \\
\hline 20 & Włodawa & 23.55 & 51.55 & 175 & 8.2 \\
\hline 21 & Wrocław & 16.88 & 51.10 & 120 & 9.4 \\
\hline 22 & Zakopane & 19.95 & 49.30 & 857 & 6.0 \\
\hline
\end{tabular}

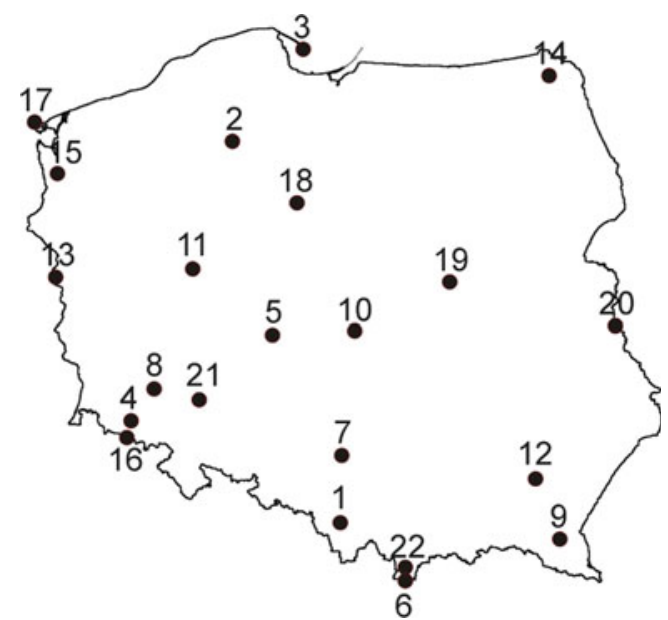

Fig. 1 Map of locations of meteorological stations used in this work

Görlitz and Potsdam (Germany); Oravska Lesna, Poprad, and Kosice (Slovakia); Lviv (Ukraine); Vilnius (Lithuania); and Kaliningrad (Russia), are not far from the territory of Poland.

The essential part of the records (daily data from 19512006) were received from Institute for Meteorology and Water Management (IMGW-PIB) in the framework of the project PBZ-KBN-086/P04/2003, "Extreme meteorological and hydrological events in Poland (assessment of events and forecasting of their impact on human environment)". More recent data were downloaded from archives of synoptic messages and Global Summary of the Day (GSOD) available on servers of NOAA, so that the complete set of data records used in this study spans the six-decade interval 1951-2010. The quality of information for 2007-2010 was validated by comparison of GSOD data for 2006 with observation records from IMGWPIB, available for the same year. Archives of synoptic messages proved to be a satisfactorily accurate source of data (Graczyk 2013).

Excursions (level crossings) of temperature beyond some characteristic thresholds are particularly important for plant growth. The threshold of $5^{\circ} \mathrm{C}$ of mean daily air temperature is being used in many methods of the thermal growing season calculation (e.g., Linderholm et al. 2008; Skaugen and Tveito 2004; Carter 1998). For cultivars that are sensitive to low temperatures, characteristics related to the minimum temperature threshold of $0{ }^{\circ} \mathrm{C}$ are important, while relevant sensitivity thresholds can be different for different plants. The rate of plant development and reaching particular development phases approximately depend on the sums of daily exceedance of some threshold temperature values, specific for each plant. This can be described via a growing degree-days (GDD) index (Górski and Jakubczak 1965). It is difficult to determine the physiological base temperature, and each growing phase may have a different base temperature (Yang et al. 1995). The base temperature can also vary depending on the used methodology. In this study, three base temperature thresholds were 
adopted. For determination of degree-days, mean daily air temperature was used here (alternatively, one may use the mean of daily maximum and minimum temperatures, e.g., Mc Master and Wilhelm 1997; Su et al. 2013).

Seven thermal indices, of importance to agriculture, were examined, namely

1. Duration of the growing season, calculated as the number of days between the last occurrence of at least 6-day interval with daily mean air temperature $<5^{\circ} \mathrm{C}$ before 1 July and the first occurrence of at least 6-day interval with daily mean air temperature $<5^{\circ} \mathrm{C}$ after $1 \mathrm{July}$, as in European Climate Assessment \& Dataset (ECA\&D), cf. Klein Tank et al. (2002).

2. Duration of the longest interval without frost, calculated as the longest continuous interval in a year with daily minimum air temperature $>0{ }^{\circ} \mathrm{C}$

3. Date of occurrence of the last spring frost, determined as the number of day in a year, when the daily minimum air temperature drops below $0{ }^{\circ} \mathrm{C}$ for the last time before 1 July

4. Date of occurrence of the first autumn frost, determined as the number of day in a year, when the daily minimum air temperature drops below $0{ }^{\circ} \mathrm{C}$ for the first time after 1 July

5-7. Growing degree-days (GDD), also called degree-days of vegetation), calculated as the sum of positive deviations of daily mean air temperature above the following threshold values: $10^{\circ} \mathrm{C}$ (threshold value for plants with high thermal requirements), $8{ }^{\circ} \mathrm{C}$ (threshold value for plants with medium thermal requirements), and $5.5^{\circ} \mathrm{C}$ (threshold value for some cereals).

Time series of annual values of the above indices were determined for each station. They were examined using the Hydrospect 2.0 software (Radziejewski and Kundzewicz 2004) developed for change detection in long time series by non-parametric Mann-Kendall test.
The following threshold values of the significance level were used in this paper:

(i) Statistically significant trend at the level of 0.05

(ii) Statistically significant trend at the level of 0.1

(iii) Weak, statistically insignificant, tendency (significance level between 0.1 and $\leq 0.25$ )

(iv) Lack of even a weak tendency (significance level $>0.25$ )

\section{Results of change detection}

3.1 The length of growing season and the frost-free season

Lengths of the growing season and of the frost-free season were determined for all stations including the high-mountain stations, for which these indices took the lowest values (on average: 86 and 50 days in a year at Kasprowy Wierch and 105 and 81, at Śnieżka, respectively). Highest values of the length of frost-free season were observed at the coastal stations: Hel (192 days) and Świnoujście (200 days).

Detection of trends with the help of statistical tests in long time series of duration of the growing season and of the frostfree season showed existence of significant increasing trend on the significance level of 0.05 for both indices at 14 and 15 stations, respectively (Fig. 2). For no stations, a statistically significant decreasing trend was detected.

On top of the formal trend detection, it is worthwhile to interpret some properties of time series of indices (Table 2). Counting the numbers of stations in which the maximum value of the duration of the growing season and of the frost-free season occurred in particular 20-year periods (1951-1970, 1971-1990, and 1991-2010), one can state that in 19511970, maximum values of either of these two indices were observed at four stations only, in 1971-1990 - at 10 stations,
Fig. 2 Trend in duration of a the growing season and $\mathbf{b}$ the frostfree season, after Mann-Kendall test

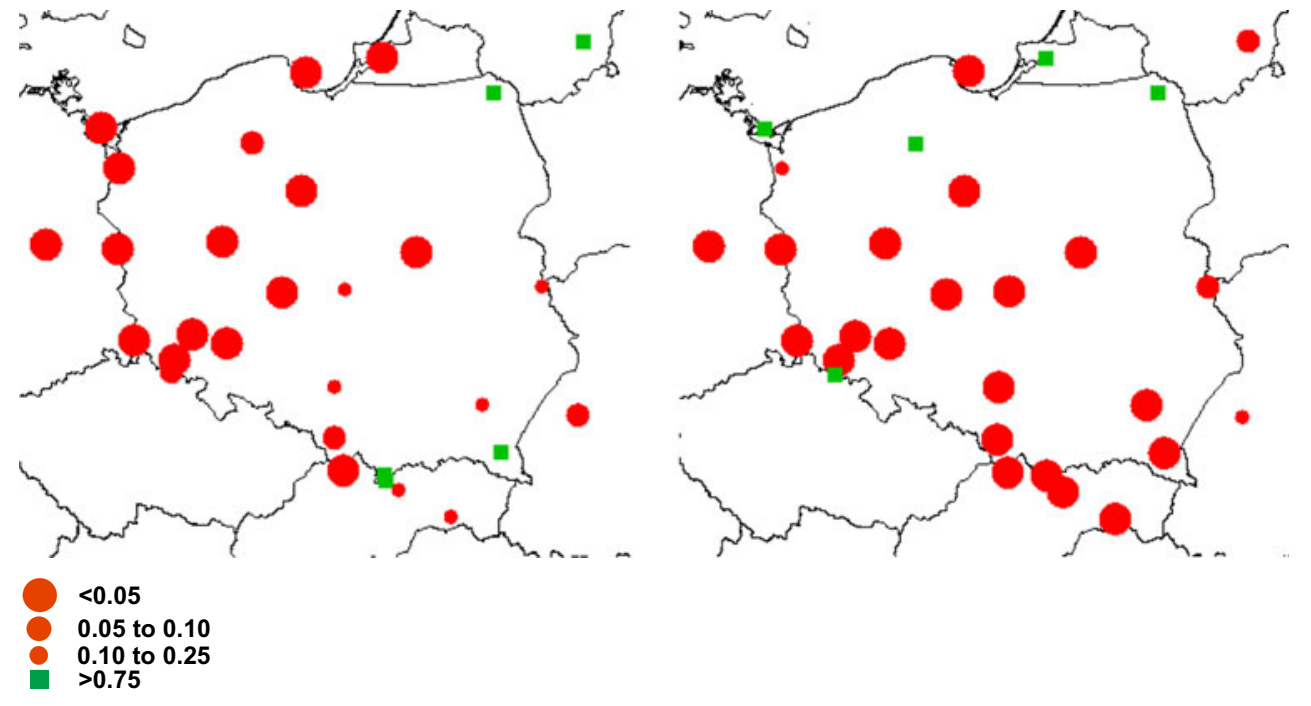


Table 2 Maximum and minimum values of duration of the growing season and of the frost-free season length at particular stations. The Table shows the duration [number of days] and the year of occurrence

\begin{tabular}{|c|c|c|c|c|c|c|c|c|c|}
\hline \multirow[t]{3}{*}{ No. } & \multirow[t]{3}{*}{ Station name } & \multicolumn{4}{|c|}{ Growing season length } & \multicolumn{4}{|c|}{ Frost-free period length } \\
\hline & & \multicolumn{2}{|l|}{$\operatorname{Max}$} & \multicolumn{2}{|l|}{ Min } & \multicolumn{2}{|l|}{ Max } & \multicolumn{2}{|l|}{ Min } \\
\hline & & Value & Year & Value & Year & Value & Year & Value & Year \\
\hline 1 & Bielsko-Biała & 313 & 2005 & 179 & 1994 & 235 & 2000 & 118 & 1973 \\
\hline 2 & Chojnice & 279 & 2002 & 174 & 1992 & 202 & 1986 & 129 & 1951 \\
\hline 3 & Hel & 313 & 2007 & 175 & 1976 & 253 & 2000 & 152 & 1976 \\
\hline 4 & Jelenia Góra & 302 & 1988 & 165 & 1951 & 173 & 2002 & 93 & 1988 \\
\hline 5 & Kalisz & 305 & 2007 & 181 & 1997 & 223 & 2000 & 141 & 1954 \\
\hline 6 & Kasprowy Wierch & 153 & 1983 & 6 & 1984 & 93 & 1982 & 16 & 1978 \\
\hline 7 & Katowice & 300 & 2007 & 188 & 1956 & 210 & 1961 & 117 & 1977 \\
\hline 8 & Legnica & 310 & 2007 & 189 & 1956 & 212 & 1961 & 127 & 1953 \\
\hline 9 & Lesko & 300 & 2007 & 180 & 1997 & 190 & 2001 & 107 & 1969 \\
\hline 10 & Łódź & 303 & 1988 & 181 & 1997 & 221 & 2008 & 119 & 1957 \\
\hline 11 & Poznań-Ławica & 310 & 2007 & 184 & 1955 & 222 & 2001 & 119 & 1957 \\
\hline 12 & Rzeszów & 300 & 2007 & 185 & 1955 & 221 & 1989 & 107 & 1977 \\
\hline 13 & Słubice & 316 & 2005 & 188 & $1951 ; 1956$ & 202 & 2001 & 109 & 1977 \\
\hline 14 & Suwałki & 255 & 2006 & 162 & 1981 & 189 & 1957 & 114 & 1982 \\
\hline 15 & Szczecin & 316 & 2005 & 184 & 1955 & 212 & 1986 & 116 & 1952 \\
\hline 16 & Śnieżka & 176 & 2007 & 25 & 1970 & 129 & 1988 & 39 & 1964 \\
\hline 17 & Świnoujście & 316 & 2005 & 180 & 1956 & 276 & 2006 & 167 & 1971 \\
\hline 18 & Toruń & 306 & 2007 & 165 & 1951 & 197 & 1989 & 113 & 1977 \\
\hline 19 & Warszawa-Okęcie & 313 & 2005 & 180 & 1997 & 221 & 2008 & 134 & 1964 \\
\hline 20 & Włodawa & 300 & 2007 & 180 & 1997 & 199 & 2008 & 115 & 1973 \\
\hline 21 & Wrocław & 305 & 2007 & 185 & 1955 & 222 & 1961 & 114 & 1991 \\
\hline 22 & Zakopane & 242 & 1973 & 152 & 1987 & 186 & 2006 & 90 & 1952 \\
\hline
\end{tabular}

in 1991-2010 - at 30 stations (at 18 stations for growing season length and at 12 stations for longest non-frost period). However, there was 1 year, 2007, when maxima of the growing season length occurred at a great number of stations (11). The occurrence of a single year with many record values of indices may confound a broader tendency.

The minimum values of the length of the growing season and of the frost-free season occurred in earlier decades more frequently than recently, but the change is weaker. The minima were observed in 1951-1970 at 21 stations, in 19711990 at 15 stations, in 1991-2010 at 8 stations (for the growing season length at 7 stations and for the frost-free season length at 1 station).

Examination of decadal changes shows that the longest vegetation season and the longest frost-free period have been observed in the 2000s (for 18 and 9 stations, respectively). For no station, the longest vegetation season was observed in the $1950 \mathrm{~s}$ or the $1960 \mathrm{~s}$, but for four stations, the longest frost-free period was observed in 1950 s or 1960 s (therein at three stations in 1961). In 2000s, at no station minimum values of the length of growing season or of the frost-free season were observed. It is worth stating that the minimum vales of duration of the growing season and of the frost-free season for high-mountain values can be very low. For Kasprowy Wierch, there was actually no summer break in cold weather in 1984, when duration of growing season was only 6 days or in 1978, when duration of frost-free season was only 16 days. Nevertheless, the high-mountain stations of Kasprowy Wierch and Śnieżka were retained for completeness, even if no agriculture is possible then. Agriculture is abundant in the foothills of the mountains (Table 2).

\subsection{Days of occurrence of last spring frost and first autumn} frost

Days of occurrence of the last spring frost (the last day between 1 January and 30 June with minimum temperature $<0{ }^{\circ} \mathrm{C}$ ) and of the first autumn frost (the first day between 1 July and 31 December with minimum temperature $<0^{\circ} \mathrm{C}$ ) were determined for 20 of 22 stations, except for two stations in high mountains, where no definite summer break in frost days could be noted (see 3.1). Spring frost days may last longest in piedmont stations: Jelenia Góra (on average up to the 135th day of the year, i.e., 15 May) and Zakopane (up to the 130th day of the year, i.e., 10 May). Spring frost days end earliest in the sea coast station Świnoujście (on average up to the 107th day of the year, i.e., 17 April). Autumn frost days start earliest, in September, in 
Fig. 3 Trend in changes in days of occurrence of a the last spring frost and $\mathbf{b}$ the first autumn frost, after Mann-Kendall test (a)

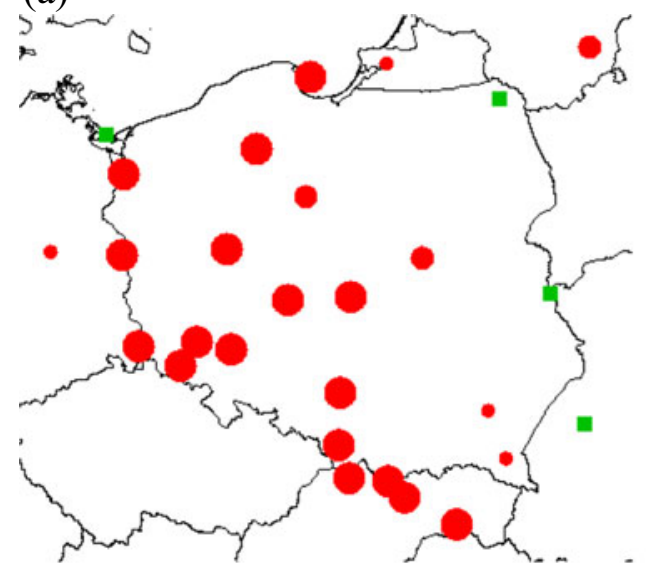

earlier occurrence later occurrence

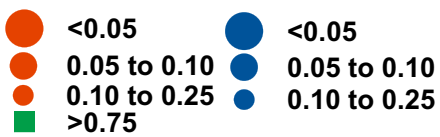

(b)

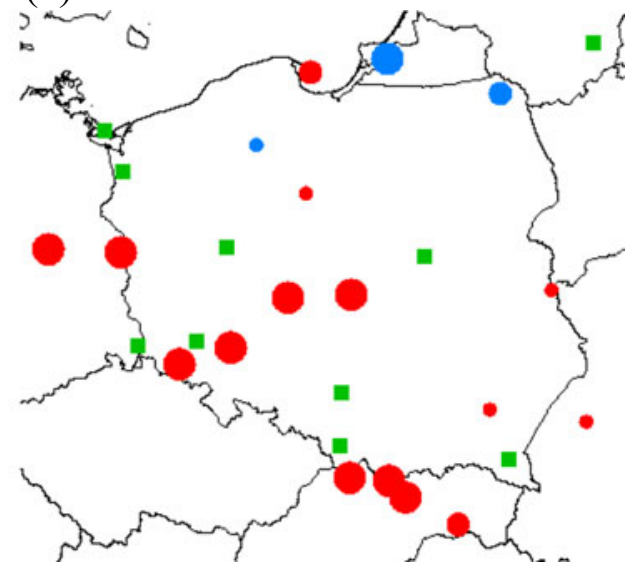

later occurrence earlier occurrence

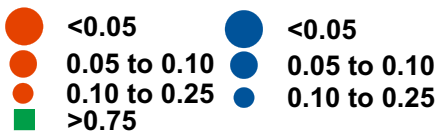

piedmont stations: Jelenia Góra on the 270th day and Zakopane on the 271st day of the year. Autumn frost days start latest, in November, in the sea coast stations Hel and Świnoujście (on average the 314th and the 311st day, respectively).

With the help of statistical tests in long-term time series of the day of the last spring frost and of the first autumn frost in
Poland (Fig. 3), trends were detected on the significance level of 0.05 at 13 (advance of the last spring frost) and 6 stations (delay of the first autumn frost), respectively. At further 2 and 2 stations, respectively, tests indicated similar trends on the significance level from the interval $0.05-0.1$. For the station Suwałki, a statistically significant decreasing trend $(0.1)$ in the
Table 3 The latest last spring frost day and the earliest first autumn frost day

\begin{tabular}{|c|c|c|c|c|c|c|c|c|c|}
\hline \multirow[t]{3}{*}{ No. } & \multirow[t]{3}{*}{ Station name } & \multicolumn{4}{|c|}{ The last spring frost day } & \multicolumn{4}{|c|}{ The first autumn frost day } \\
\hline & & \multicolumn{2}{|c|}{ The latest } & \multicolumn{2}{|c|}{ The earliest } & \multicolumn{2}{|c|}{ The earliest } & \multicolumn{2}{|c|}{ The latest } \\
\hline & & Value & Year & Value & Year & Value & Year & Value & Year \\
\hline 1 & Bielsko-Biała & 152 & 1977 & 90 & 2008 & 269 & 1957 & 323 & 2008 \\
\hline 2 & Chojnice & 150 & 1977 & 100 & 2002 & 260 & 1977 & 319 & 1963 \\
\hline 3 & Hel & 151 & 1951 & 88 & 2008 & 271 & 1966 & 354 & 2000 \\
\hline 4 & Jelenia Góra & 158 & 1962 & 107 & 2002 & 248 & 1953 & 293 & 1978 \\
\hline 5 & Kalisz & 140 & 1952 & 79 & 1999 & 256 & 1973 & 328 & 1996 \\
\hline 6 & Katowice & 150 & 1955 & 100 & 2002 & 245 & 1956 & 321 & 1989 \\
\hline 7 & Legnica & 140 & 1952 & 91 & 2009 & 250 & 1991 & 314 & 2001 \\
\hline 8 & Lesko & 157 & 1958 & 100 & $1989 ; 2002$ & 252 & 1969 & 307 & 1984 \\
\hline 9 & Łódź & 151 & 1966 & 99 & 1963 & 259 & 1959 & 322 & 2008 \\
\hline 10 & Poznań-Ławica & 147 & 1957 & 100 & $1961 ; 2008$ & 250 & 1991 & 324 & 2000 \\
\hline 11 & Rzeszów & 152 & 1977 & 94 & 1989 & 256 & 1973 & 316 & $1989 ; 2008$ \\
\hline 12 & Słubice & 151 & 1977 & 91 & 1961 & 245 & 2003 & 314 & 2001 \\
\hline 13 & Suwałki & 161 & 1982 & 99 & 2002 & 258 & 1999 & 316 & 1957 \\
\hline 14 & Szczecin & 148 & 1957 & 95 & 1983 & 259 & 1952 & 326 & 2008 \\
\hline 15 & Świnoujście & 131 & 1978 & 85 & $1998 ; 2006$ & 285 & 1973 & 362 & 2006 \\
\hline 16 & Toruń & 152 & 1975 & 105 & 1998 & 256 & 1971 & 311 & 1974 \\
\hline 17 & Warszawa-Okęcie & 144 & 1991 & 95 & 1989 & 269 & 1977 & 322 & 2008 \\
\hline 18 & Włodawa & 148 & 1990 & 97 & 2002 & 254 & 1973 & 302 & 1974 \\
\hline 19 & Wrocław & 149 & 1957 & 91 & 2009 & 250 & 1991 & 323 & 1961 \\
\hline 20 & Zakopane & 154 & 1977 & 103 & 2006 & 246 & 1958 & 295 & 1980 \\
\hline
\end{tabular}


Threshold: $10^{\circ} \mathrm{C}$

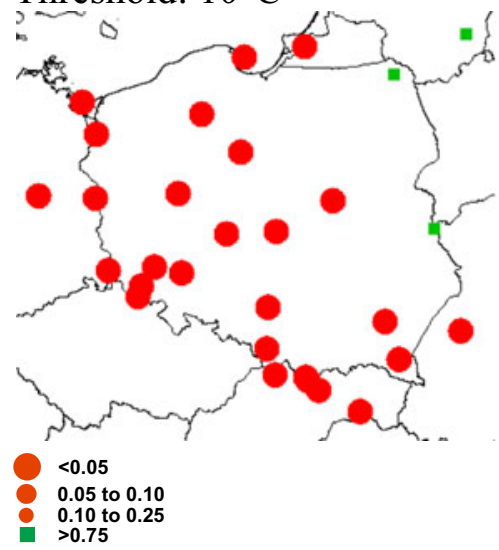

Threshold: $8^{\circ} \mathrm{C}$

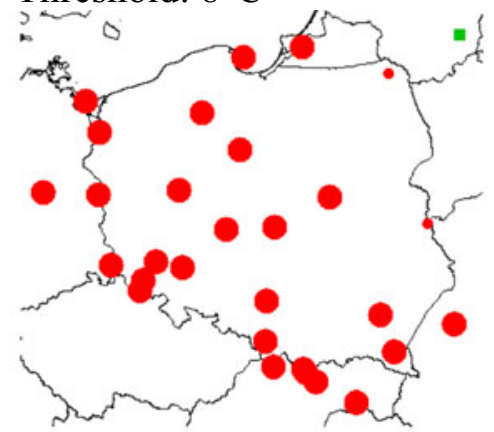

Threshold: $5.5^{\circ} \mathrm{C}$

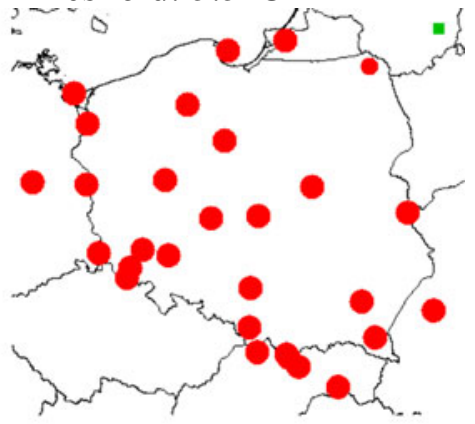

Fig. 4 Trend in changes in annual sums of GDD, for three threshold values of 10 , 8, and $5.5^{\circ} \mathrm{C}$, after Mann-Kendall test

date of the first autumn frost was detected, i.e., the autumn frost comes earlier there. This is counterintuitive.

The earliest last spring frost day occurred predominantly in the 2000s (16 stations) and in particular in 2002 (6 stations) and the latest last spring frost day in the 1950s (8 stations) and in the 1970s (7 stations), in particular in 1977 (5 stations) and

Table 4 Maximum values of annual sums of GDD, for three threshold values of 10,8 , and $5.5^{\circ} \mathrm{C}$. Values of GDD were rounded to nearest integer

\begin{tabular}{|c|c|c|c|c|c|c|c|}
\hline \multirow[t]{2}{*}{ No. } & \multirow[t]{2}{*}{ Station name } & \multicolumn{2}{|c|}{$\begin{array}{l}\text { Threshold: } \\
10^{\circ} \mathrm{C}\end{array}$} & \multicolumn{2}{|c|}{$\begin{array}{l}\text { Threshold: } \\
8^{\circ} \mathrm{C}\end{array}$} & \multicolumn{2}{|c|}{$\begin{array}{l}\text { Threshold: } \\
5.5^{\circ} \mathrm{C}\end{array}$} \\
\hline & & Value & Year & Value & Year & Value & Year \\
\hline 1 & Bielsko-Biała & 1198 & 2006 & 1609 & 2006 & 2200 & 2000 \\
\hline 2 & Chojnice & 1073 & 2006 & 1434 & 2006 & 1902 & 2002 \\
\hline 3 & Hel & 1070 & 2006 & 1451 & 2006 & 2010 & 2006 \\
\hline 4 & Jelenia Góra & 989 & 2002 & 1312 & 2006 & 1850 & 2006 \\
\hline 5 & Kalisz & 1301 & 2006 & 1708 & 2006 & 2280 & 2006 \\
\hline 6 & Kasprowy Wierch & 111 & 1994 & 222 & 2003 & 453 & 2003 \\
\hline 7 & Katowice & 1203 & 2003 & 1576 & 2006 & 2141 & 2006 \\
\hline 8 & Legnica & 1301 & 2003 & 1711 & 2006 & 2298 & 2006 \\
\hline 9 & Lesko & 1046 & 1963 & 1355 & 2003 & 1920 & 2002 \\
\hline 10 & Łódź & 1236 & 2006 & 1634 & 2006 & 2098 & 2002 \\
\hline 11 & Poznań-Ławica & 1350 & 2006 & 1758 & 2006 & 2333 & 2006 \\
\hline 12 & Rzeszów & 1220 & 2002 & 1613 & 2006 & 2170 & 2006 \\
\hline 13 & Słubice & 1338 & 2006 & 1766 & 2006 & 2358 & 2006 \\
\hline 14 & Suwałki & 1090 & 2002 & 1420 & 2002 & 1883 & 2002 \\
\hline 15 & Szczecin & 1175 & 1992 & 1708 & 2006 & 2305 & 2006 \\
\hline 16 & Śnieżka & 188 & 2006 & 331 & 2003 & 604 & 2006 \\
\hline 17 & Świnoujście & 1162 & 2006 & 1562 & 2006 & 2152 & 2006 \\
\hline 18 & Toruń & 1221 & 2006 & 1609 & 2006 & 2177 & 2006 \\
\hline 19 & Warszawa-Okęcie & 1311 & 2006 & 1704 & 2006 & 2265 & 2006 \\
\hline 20 & Włodawa & 1226 & 2002 & 1580 & 2002 & 2127 & 1963 \\
\hline 21 & Wrocław & 1291 & 2006 & 1699 & 2006 & 2279 & 2006 \\
\hline 22 & Zakopane & 682 & 1994 & 1054 & 2003 & 1509 & 2000 \\
\hline
\end{tabular}

1957 (3 stations). The earliest first autumn frost day occurred predominantly in the 1970s (7 stations) and in the 1950s (6 stations), but it also occurred in the 1990s (4 stations) and in the 2000s (1 station) and the latest first autumn frost day in the 2000s (9 stations), therein in 2008 at 5 stations. This is consistent with the warming, but the inter-decadal variability is

Table 5 Minimum values of annual sums of GDD, for three threshold values of 10,8 , and $5.5^{\circ} \mathrm{C}$. Values of GDD were rounded to nearest integer

\begin{tabular}{|c|c|c|c|c|c|c|c|}
\hline \multirow[t]{2}{*}{ No. } & \multirow[t]{2}{*}{ Station name } & \multicolumn{2}{|c|}{$\begin{array}{l}\text { Threshold: } \\
10^{\circ} \mathrm{C}\end{array}$} & \multicolumn{2}{|c|}{$\begin{array}{l}\text { Threshold: } \\
8{ }^{\circ} \mathrm{C}\end{array}$} & \multicolumn{2}{|c|}{$\begin{array}{l}\text { Threshold: } \\
5.5{ }^{\circ} \mathrm{C}\end{array}$} \\
\hline & & Value & Year & Value & Year & Value & Year \\
\hline 1 & Bielsko-Biała & 625 & 1978 & 962 & 1978 & 1451 & 1980 \\
\hline 2 & Chojnice & 540 & 1965 & 840 & 1987 & 1296 & 1987 \\
\hline 3 & $\mathrm{Hel}$ & 561 & 1962 & 882 & 1962 & 1349 & 1965 \\
\hline 4 & Jelenia Góra & 521 & 1978 & 833 & 1978 & 1292 & 1980 \\
\hline 5 & Kalisz & 709 & 1980 & 1042 & 1980 & 1530 & 1980 \\
\hline 6 & Kasprowy Wierch & 1 & 1978 & 18 & 1978 & 106 & 1978 \\
\hline 7 & Katowice & 666 & 1978 & 1001 & 1980 & 1481 & 1980 \\
\hline 8 & Legnica & 744 & 1978 & 1090 & 1980 & 1591 & 1980 \\
\hline 9 & Lesko & 538 & 1978 & 858 & 1978 & 1340 & 1980 \\
\hline 10 & Łódź & 661 & 1980 & 980 & 1980 & 1455 & 1980 \\
\hline 11 & Poznań-Ławica & 734 & 1980 & 1066 & 1980 & 1560 & 1980 \\
\hline 12 & Rzeszów & 660 & 1978 & 999 & 1978 & 1496 & 1978 \\
\hline 13 & Słubice & 732 & 1962 & 1079 & 1962 & 1570 & 1962 \\
\hline 14 & Suwałki & 521 & 1987 & 807 & 1987 & 1227 & 1987 \\
\hline 15 & Szczecin & 780 & 1980 & 994 & 1962 & 1542 & 1965 \\
\hline 16 & Śnieżka & 31 & 1956 & 78 & 1980 & 208 & 1980 \\
\hline 17 & Świnoujście & 596 & 1962 & 933 & 1962 & 1420 & 1962 \\
\hline 18 & Toruń & 702 & 1965 & 1003 & 1965 & 1443 & 1965 \\
\hline 19 & Warszawa-Okęcie & 715 & 1978 & 1049 & 1980 & 1521 & 1965 \\
\hline 20 & Włodawa & 641 & 1978 & 954 & 1978 & 1437 & 1978 \\
\hline 21 & Wrocław & 735 & 1978 & 1081 & 1980 & 1576 & 1965 \\
\hline 22 & Zakopane & 268 & 1978 & 495 & 1980 & 887 & 1978 \\
\hline
\end{tabular}


Table 6 Numbers of stations at which statistically significant trends in temperature-related agroclimatic indices were observed, for two significance levels: 0.05 and 0.1

\begin{tabular}{lll}
\hline Index & $\begin{array}{l}\text { Statistical } \\
\text { significance: } \\
0.05\end{array}$ & $\begin{array}{l}\text { Statistical } \\
\text { significance: } \\
0.1\end{array}$ \\
\hline $\begin{array}{l}\text { Length of the growing season } \\
\begin{array}{l}\text { Length of the frost-free season } \\
\text { Date of occurrence of last spring frost }\end{array}\end{array}$ & $\begin{array}{l}11 \text { of } 22 \\
13 \text { of } 22\end{array}$ & $\begin{array}{l}14 \text { of } 22 \\
16 \text { of } 22 \\
15 \text { of } 20\end{array}$ \\
$\begin{array}{l}\text { Date of occurrence of first autumn frost } \\
\text { Annual sums of growing degree-days } \\
\text { for the threshold value of } 10^{\circ} \mathrm{C}\end{array}$ & 20 of 22 & 20 of 20 \\
$\begin{array}{c}\text { Annual sums of growing degree-days } 22 \\
\text { for the threshold value of } 8{ }^{\circ} \mathrm{C}\end{array}$ & 20 of 22 & 20 of 22 \\
$\begin{array}{c}\text { Annual sums of growing degree-days } \\
\text { for the threshold value of } 5.5^{\circ} \mathrm{C}\end{array}$ & 21 of 22 & 22 of 22 \\
\hline
\end{tabular}

strong (e.g., at some stations record cold indices were observed in the 1970s) (Table 3).

\subsection{Annual sums of growing degree-days}

The annual sums of GDD (also called degree-days of vegetation) were calculated for all 22 stations in Poland and for three threshold values of 10,8 , and $5.5^{\circ} \mathrm{C}$. The lowest values of this index, for the three thresholds, as noted above, occurred at highmountain stations: Kasprowy Wierch (on average, 45, 114, and 280 degree-days, respectively, in a year) and Śnieżka (90, 190, and 398 degree-days, respectively, in a year). In the area of these stations, climate is too harsh for vegetation. Low values were also observed at a piedmont station in Zakopane (below 850,1000 , and below 1600 degree-days, respectively, in a year), in coastal stations: Hel and Świnoujście and in a southeast station, Suwałki. The highest values of GDD were observed in most lowland stations, except for northeast.

Detection of trends with the help of statistical tests in longterm time series of annual sums of GDD (Fig. 4), for three threshold values of 10,8 , and $5.5^{\circ} \mathrm{C}$, showed existence of trend on the significance level of 0.01 at 20, 20, and 21 (of 22) stations, respectively. At some stations, significance level was very high: 0.0001 (e.g., for $5.5^{\circ} \mathrm{C}$ threshold at 10 stations: BielskoBiała, Jelenia Góra, Kalisz, Katowice, Legnica, Rzeszów, Słubice, Szczecin, Torun, and Wrocław). The weakest significance level for $5.5^{\circ} \mathrm{C}$ threshold was 0.0557 for Suwałki. In none of the analyzed series a downward trend was detected.

The highest annual sums of GDD - degree-days of vegetation (Table 4), for three temperature threshold values of 10 , 8 , and $5.5^{\circ} \mathrm{C}$ occurred predominantly in the $2000 \mathrm{~s}$ ( 18 stations for $10{ }^{\circ} \mathrm{C}$, all 22 stations for $8{ }^{\circ} \mathrm{C}$, and 19 for $5.5^{\circ} \mathrm{C}$ ). In a single record year, 2006, the highest index of GDD occurred in 12,16 , and 14 stations, respectively, for the three thresholds considered. Only for two stations the maxima occurred in the first 20 years of observations. In 1963, the maximum of GDD in Lesko for the $10^{\circ} \mathrm{C}$ threshold occurred and in Włodawa for the $5.5^{\circ} \mathrm{C}$ threshold.

Surprisingly, record low annual sums of GDD (Table 5) for three threshold values of 10,8 , and $5.5^{\circ} \mathrm{C}$ occurred mostly not in 1950s but in two individual years, 1978 and 1980. In a single year, 1980, the lowest value of GDD occurred, respectively, in 4, 9, and 9 stations, while in 1978, the lowest index of GDD occurred, respectively, in 11, 6, and 4 stations. The minimum GDD values for all thresholds occurred in 1980 in Kalisz, Łódź, and Poznań-Ławica, while in 1978 in Kasprowy Wierch, Rzeszów, and Włodawa.

\subsection{Summary of observed trends in temperature-related agroclimatic indices}

The three classes of thermal indices of relevance to agriculture tackled in this paper vary in terms of the number of stations with detected significant trends (Table 6). The highest percentage of significant changes was found for three indices of the annual sums of growing degree-days for various temperature thresholds. In particular, the GDD index for the $5.5^{\circ} \mathrm{C}$ threshold is significant at the 0.1 level at all the 22 stations and at the 0.05 level for all but one station (i.e., 21 out of 22). The remaining two classes of indices have a lower percentage of stations with significant changes. In particular, the change (delay) in date of occurrence of first autumn frost is significant

\section{C4IRCA3}

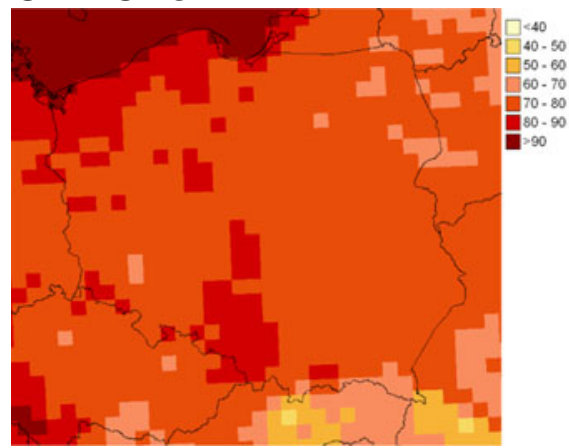

\section{METO-HC}

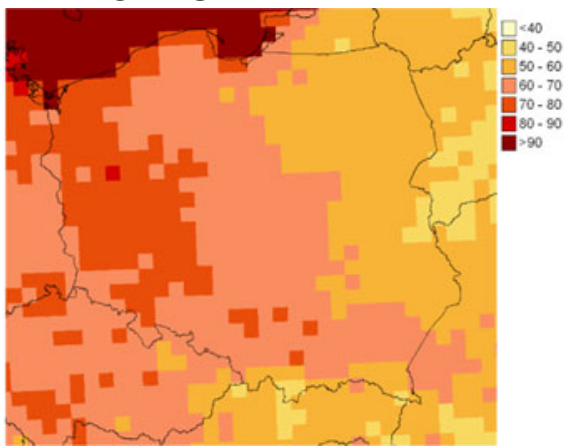

MPI-M-REMO

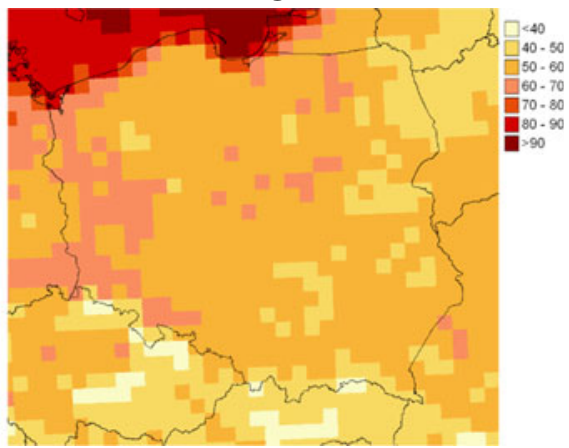

Fig. 5 Changes in growing season length - projections of three regional climate models (difference between 2061-2090 and 1961-1990) 

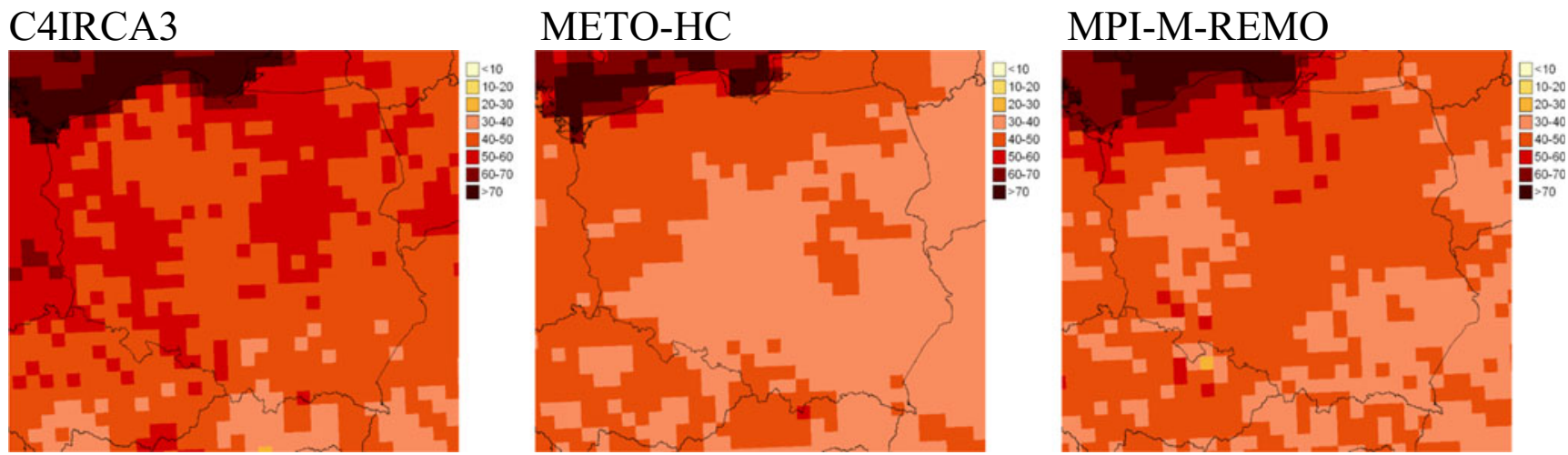

Fig. 6 Changes in frost-free season length - projections of three regional climate models (difference between 2061-2090 and 1961-1990)

at 8 stations ( $40 \%$ of the total number) at the 0.1 level and at 6 stations only (30\% of the total number) at the 0.05 level.

\section{Projections of changes of temperature-related agroclimatic indices}

Simulations made with the help of regional climate models in the ENSEMBLES Project were used to quantify agroclimatic indices. Results from 3 of 15 available regional climate models have been chosen (Graczyk 2013) that fit best to the climate conditions in Poland (instrumental data in the control period of 1961-1990). They are MPI-M-REMO from the Max Planck Institute (Hamburg, Germany), METO-HC from the Met Office's Hadley Centre (Exeter, UK), and C4IRCA3 from the Rossby Centre (Norrköping, Sweden). The selected regional climate models with resolution about $25 \mathrm{~km}$ (600 cells over the territory of Poland) were forced by two different global circulation models (GCM). METO-HC and C4IRCA3 regional models were constructed based on METO-HC GCM, whereas MPI-M-REMO was driven by the 5th generation of the ECHAM GCM (cf. Szwed et al. 2010). Model-based simulations were considered for two future time horizons, a century apart, i.e., 1961-1990 and 2061-2090, for SRES A1B scenario (Nakicenovic et al. 2000).
On average, the growing season is projected to increase, depending on a model, by 40-60 days in the east of Poland and even by 70-90 days on the west (Fig. 5), where it will increase to nearly 300 days in a year. In the northeast of Poland, where the vegetation season is shortest, it will exceed 250 days (average from three models for the Suwałki area). According to one of the models (C4IRCA3), in warmest years, the growing season is projected to last nearly whole year (over 350 days) over most of Poland.

According to three models, the frost-free season will lengthen by 40-70 days. The increase will be highest where the frost-free season is at its shortest now. This also means that the date of occurrence of the last spring frost and the first autumn frost will be shifted. According to projections, based on the MPI-M-REMO simulations, the frost-free season will lengthen in western Poland by less than 40 days (Fig. 6).

The spring frost in Poland will end between the 50th and the 110th day of the year, depending on a model and a region. In the Baltic coast, the last spring frost will occur earliest in February and in foothills and east of Poland latest in midApril. Similarly, the first autumn frost will be delayed, occurring between mid-October and beginning of December.

Projected changes for 2061-2090 in GDD for all three temperature thresholds considered, i.e., 10,8 , and $5.5^{\circ} \mathrm{C}$, defined with reference to the control period 1961-1990

\section{C4IRCA3}

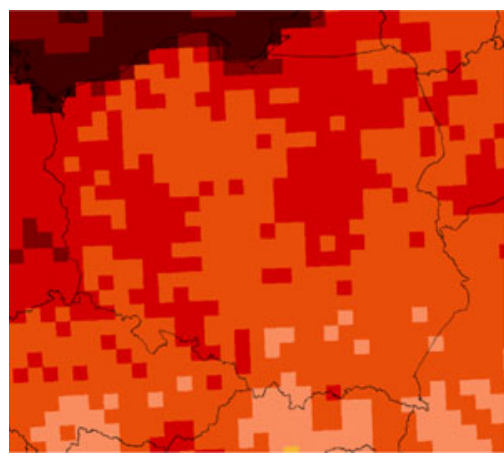

METO-HC

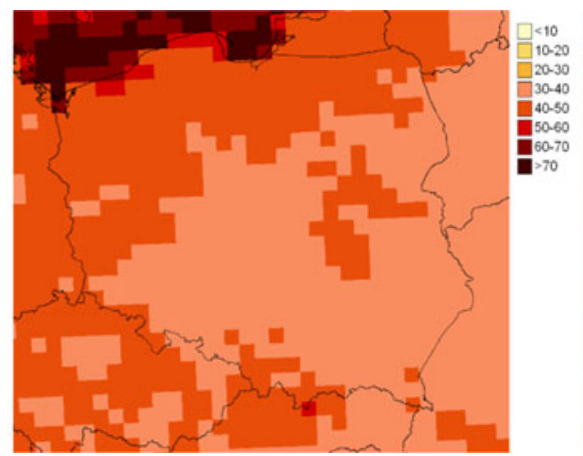

MPI-M-REMO

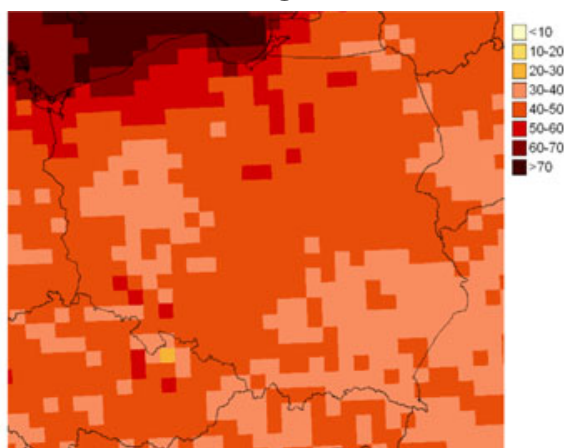

Fig. 7 Changes in growing degree-days (GDD) for the $10{ }^{\circ} \mathrm{C}$ threshold - projections of three regional climate models (difference between $2061-2090$ and 1961-1990) 
demonstrate regular increases. For $10{ }^{\circ} \mathrm{C}$ threshold (Fig. 7), according to the C4IRCA3 and the METO-HC models, the mean GDD values will increase by more than 500 degree-days over a large area of Poland. In projections by the MPI-MREMO model, the changes are lower than in simulations by other models - in the belt covering most of Poland, the increase should not exceed 400 degree-days. For $8^{\circ} \mathrm{C}$ threshold, the largest increase, according to the METO-HC model, exceeding 800 degree-days, is possible in the south and southwest of Poland. For $5.5{ }^{\circ} \mathrm{C}$ threshold, the increase exceeds 1000 degree-days in the METO-HC model projections.

\section{Discussions and conclusions}

The analysis reported in this paper sheds light on the behavior of the time series of seven indices at 22 meteorological stations in Poland, spanning the interval of 1951-2010. Trend detection was carried out, with the help of the Mann-Kendall test.

Consistently with the warming, an increase in "warm" indices has been observed, such as the lengths of the growing season and of the frost-free season, the date of occurrence of first autumn frost, and the annual sums of growing degreedays for three temperature threshold values. The date of occurrence of last spring frost, i.e., where increase would correspond to cooling, has decreased, consistently with the warming.

As expected, detected changes correspond to the overwhelming and ubiquitous warming. However, strong natural variability is noted; hence, the trends are not of ubiquitous statistical significance. Nevertheless, for no station and no index, a statistically significant trend (significance level $\leq 0.05$ ) corresponding to cooling was noted in Poland.

The highest values of "warm" indices have been observed, with few exceptions, in the last two decades analyzed, 19912010.

These results are consistent with the studies of thermal characteristics of importance to agriculture in Poland, Europe, and other continents. Extension of the thermal growing season has been observed for many areas, with use of different observation periods and calculation methods (Carter 1998; Menzel et al. 2003; Żmudzka 2004; Linderholm 2006; Linderholm et al. 2008; Dong et al. 2013). This is also confirmed by phenological observations in some regions (Menzel 2000; Chen et al. 2005; Lou et al. 2013).

Changes of thermal characteristics associated with the occurrence of frost, in line with those described in this paper, have been identified by Menzel et al. (2003), Kunkel et al. (2004), and Bielec-Bakowska and Piotrowicz (2011).

Changes in growing degree-days presented in this research are consistent with the results of other studies, in which an increase of this indicator has been also observed for different values of temperature thresholds (Kadioglu and Saylan 2001; Feng and Hu 2004; Żmudzka 2012).

Based on our analysis of projections via climate models, further improvement of thermal characteristics of importance to agriculture can be expected, even if the first autumn frost can come quite early even in the warmer climate.

Nevertheless, this paper only deals with temperature-related agroclimatic indices. Here, all thermal changes (ceteris paribus) look beneficial for agriculture. However, such an observation would be misleading, because of other factors driving crop yield. It is likely that changes in yield will be driven by hydrothermal conditions: advantageous changes in temperature and disadvantageous changes in availability of soil moisture. Indeed, the water availability can be a limiting factor. The seasonal distribution of precipitation has already adversely changed (the ratio of precipitation total in warm half-year to precipitation total in cold half-year has decreased) and even stronger adverse changes are projected in the future (Pińskwar 2010). This is so, because of likely increase of frequency, intensity, and duration of soil moisture droughts as well as of intense precipitation and flooding, even if models are not in agreement to quantitative changes in projections of spring and summer precipitation. Longer periods with soil moisture deficit (and inadequate water availability potential for massive irrigation) will likely be interspersed by intense precipitation episodes.

The results obtained in this study are of considerable societal and economic importance. Improving the insight and understanding of changes in agroclimatic indices is relevant and timely.

Acknowledgments This study was sponsored by the Ministry of Science and Higher Education and the National Science Centre of the Republic of Poland, under a doctoral research grant "Analysis of thermal conditions of Poland on the background of the climate of Europe, based on observations and projections of temperature" (No. 3782/B/P01/2010/ 39). The Institute of Meteorology and Water Management-State Research Institute (IMGW-PIB) is kindly acknowledged for the provision of meteorological data.

Open Access This article is distributed under the terms of the Creative Commons Attribution License which permits any use, distribution, and reproduction in any medium, provided the original author(s) and the source are credited.

\section{References}

Bielec-Bąkowska Z, Piotrowicz K (2011) Wieloletnia zmienność okresu bezprzymrozkowego w Polsce w latach 1951-2006. Pr Stud Geogr 47:77-86

Carter TR (1998) Changes in the thermal growing season in Nordic countries during the past century and prospects for the future. Agric Food Sci Finl 7:161-179

Chen XQ, Hu B, Yu R (2005) Spatial and temporal variation of phenological growing season and climate change impacts in temperate eastern China. Glob Chang Biol 11:1118-1130 
Dong MY, Jiang Y, Zhang DY, Wu ZF (2013) Spatiotemporal change in the climatic growing season in Northeast China during 1960-2009. Theor Appl Climatol 111:693-701

Feng S, Hu Q (2004) Changes in agro-meteorological indicators in the contiguous United States: 1951-2000. Theor Appl Climatol 78: $247-264$

Górski T, Jakubczak Z (1965) W sprawie metody sum temperatur w agrometeorologii. Rocz Nauk Rol A 90(2):215-231

Graczyk D (2013) Warunki temperaturowe Polski w zmieniającym się klimacie Europy. Doctoral dissertation, Department of Melioration and Environmental Engineering, University of Life Sciences in Poznań, Poland

Kadioglu M, Saylan L (2001) Trends of growing degree-days in Turkey. Water Air Soil Pollut 126:83-96

Klein Tank AMG, Wijngaard JB, Können GP, Böhm R, Demarée G, Gocheva A, Mileta M, Pashiardis S, Hejkrlik L, Kern-Hansen C, Heino R, Bessemoulin P, Müller-Westermeier G, Tzanakou M, Szalai S, Pálsdóttir T, Fitzgerald D, Rubin S, Capaldo M, Maugeri M, Leitass A, Bukantis A, Aberfeld R, van Engelen AFV, Forland E, Mietus M, Coelho F, Mares C, Razuvaev V, Nieplova E, Cegnar T, Antonio López J, Dahlström B, Moberg A, Kirchhofer W, Ceylan A, Pachaliuk O, Alexander LV, Petrovic P (2002) Daily dataset of 20thcentury surface air temperature and precipitation series for the European Climate Assessment. Int J Climatol 22:1441-1453

Kunkel KE, Easterling DR, Hubbard K et al (2004) Temporal variations in frost-free season in the United States: 1895-2000. Geophys Res Lett 31:art. no. L03201

Linderholm HW (2006) Growing season changes in the last century. Agric For Meteorol 137:1-14

Linderholm HW, Walther A, Chen DL (2008) Twentieth-century trends in the thermal growing season in the Greater Baltic Area. Clim Change 87:405-419

Lou W, Sun K, Sun S, Ma F, Wang D (2013) Changes in pick beginning date and frost damage risk of tea tree in Longjing tea-producing area. Theor Appl Climatol 114:115-123

Mc Master GS, Wilhelm WW (1997) Growing degree-days: one equation, two interpretations. Agric For Meteorol 87:291-300
Menzel A (2000) Trends in phenological phases in Europe between 1951 and 1996. Int J Biometeorol 44:76-81

Menzel A, Jakobi G, Ahas R, Scheifinger H, Estrella N (2003) Variations of the climatological growing season (1951-2000) in Germany compared with other countries. Int $\mathrm{J}$ Climatol 23:793-812

Nakicenovic N, Alcamo J, Davis G, de Vries B, Fenhann J, Gaffin S, Gregory K, Grübler A, Jung TY, Kram T, La Rovere EL, Michaelis L, Mori S, Morita T, Pepper W, Pitcher H, Price L, Riahi K, Roehrl A, Rogner HH, Sankovski A, Schlesinger M, Shukla P, Smith S, Swart R, van Rooijen S, Victor N, Dadi Z (2000) IPCC special report on emissions scenarios. Cambridge University Press, Cambridge

Pińskwar I (2010) Projections of changes in precipitation extremes in Poland. Monografie Komitetu Gospodarki Wodnej PAN, No. 32, Warszawa, $153 \mathrm{pp}$

Radziejewski M, Kundzewicz ZW (2004) Hydrospect, Version 2.0. User's manual

Skaugen TE, Tveito OE (2004) Growing season and degree-day scenario in Norway for 2021-2050. Clim Res 26:221-232

Su L, Wang Q, Yungang B (2013) An analysis of yearly trends in growing degree days and the relationship between growing degree day values and reference evapotranspiration in Turpan area. China Theor Appl Climatol 113:711-724

Szwed M, Karg G, Pińskwar I, Radziejewski M, Graczyk D, Kędziora A, Kundzewicz ZW (2010) Climate change and its effect on agriculture, water resources and human health sectors in Poland. Nat Hazards Earth Syst Sci 10:1725-1737

Yang S, Logan J, Coffey DL (1995) Mathematical formulae for calculating the base temperature for growing degree days. Agric For Meteorol 74:61-74

Żmudzka E (2004) Tło klimatyczne produkcji rolniczej w Polsce w drugiej połowie XX w. Acta Agrophysica [105] 3(2):399-408

Żmudzka E (2012) Wieloletnie zmiany zasobów termicznych w okresie wegetacyjnym i aktywnego wzrostu roślin w Polsce. WodaŚrodowisko-Obszary Wiejskie 12(2):377-389 